\title{
Bata Bertulis Kaitannya dengan Bangunan Candi 1 Bumiayu
}

\section{Retno Purwanti}

Keywords: inscription, gold plate, inscribed brick, Bumiayu temple, Srivijaya

\section{How to Cite:}

Purwanti, R. Bata Bertulis Kaitannya dengan Bangunan Candi 1 Bumiayu. Berkala Arkeologi, 14(2), 207-212. https:// doi.org/10.30883/jba.v14i2.725

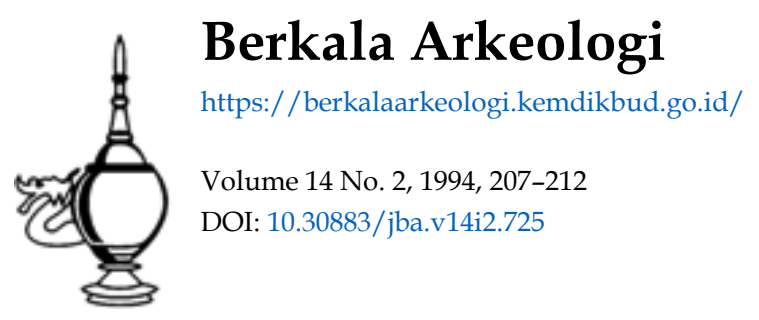

\section{(i) (2) (2)}

This work is licensed under a Creative Commons Attribution-NonCommercial-ShareAlike 4.0 International License. 


\title{
BATA BERTULIS KAITANNYA DENGAN BANGUNAN CANDI 1 BUMIAYU
}

\author{
Retno Purwanti \\ (Balai Arkeologi Palembang)
}

\section{Pendahuluan}

Bagı para peneliti sejarah yang bermaksud mengadakan penelitian mengenai permasalahan tentang sejarah Indonesia kuno, maka sumber-sumber penulisan sejarah merupakan syarat utama yang tidak mungkin diabaikan. Sumbersumber penulisan sejarah Indonesia kuna meliputi prasast, hasil kesusasteraan, peninggalanpeninggalan arkeologis dan berita-berita asing (Boechari, 1982:6). Dibandingkan dengan sumber-sumber lain, prasasti memiliki keunggulan tersendiri. Dari prasasti dapat diketahui tentang struktur kerajaan, struktur birokrasi, struktur kemasyarakatan, struktur perekonomian, agama, kepercayaan dan adat-istiadat masyarakat kuno Indonesia (Boechari, 1977). Di samping itu dapat diketahui pula unsur-unsur pertanggalan secara tepat Keunggulan-keunggulan inilah yang membuat para pakar sejarah menempatkan prasasti sebagai sumber data yang utama di antara sumber-sumber penulisan sejarah yang lain Meskıpun demikıan, tidak semua prasasti yang ditemukan memuat uraian-uraian yang lengkap seperti yang terdapat pada prasasti Kudadu dan Ducangan Bahkan sejumlah prasasti ditemukan dalam keadaan tidak utuh lagi atau hanya memuat beberapa kata saja, misalnya angka tahun atau nama raja.

Dari sejumlah prasasti-prasasti yang pernah ditemukan di Indonesia, beberapa di antaranya ditemukan di Palembang dan sekitamya. Prasasti-prasasti tersebut biasanya dikaitkan Jengan keberadaan kerajaan Sriwijaya. Berdasarkan prasasti-prasast dan tinggalan-tinggalan arkeologıs yang ditemukan di Sumatera Selatan umumnya dan Palembang khususnya, beberapa ahll mengemukakan bahwa pusat kerajaan Sriwijaya ada di Palembang. Kerajaan tersebut berkembang sejak abad ke-7 sampai ke-13 M. Asumsı tersebut didukung pula dengan beritaberita asing (Cina, Arab dan Portugis). Walaupun demikian, bukan berarti gambaran tentang kerajaan ini sudah dapat diketahui seluruhnya, melaınkan justru sebaliknya. Hal ini dikarenakan masih kurangnya data yang didapatkan kembali, sehingga usaha untuk merekonstruksi Sriwijaya dengan segala aspek kehidupannya masih jauh dari lengkap. Misalnya saja tentang kehidupan masyarakatnya. Oleh karena itulah, penemuanpenemuan data baru, baik prasasti maupun data arkeologis lainnya dapat memperkaya dan melengkapi khasanah sejarah indonesıa.
Temuan baru berupa fragmen prasastı dan data arkeologis di situs Bumiayu, Kecamatan Tanah Abang, Kabupaten Muara Enım, Sumatera Selatan, membuktikan adanya budaya laın dı samping Sriwijaya yang selama inı menoomınasi sejarah lokal Sumatera Selatan

\section{Data Arkelogis Situs Tanah Abang}

Peninggalan arkeologis berupa sisa-sisa bangunan candi ditemukan di Desa Bumiayu, Kecamatan Perwakilan Tanah Abang, Kabupaten Muara Enim, Propinsi Sumatera Selatan Daerah tersebut berada pada garis $3^{\circ} 1959^{\prime \prime}$ LS $104^{\circ} 5^{\prime} 5,45^{\prime \prime}$ BT. Sampai saat ini telah berhasil ditemukan tidak kurang 9 buah gundukan tanan dengan sebaran bata pada permukaannya, yang mengindikasikan adanya bangunan candi

Berdasarkan hasil ekskavası yang dilakukan tahun 1992 oleh Puslit Arkenas dapat diketahui, bahwa Candi 1 berdenah persegi panjang dengan ukuran $10 \times 16 \mathrm{~m}$. Pintu masuk bangunan candi terletak di sebelah timur laut menghadap ke arah Sungai Lematang. Di sebelah kirı dan kanan pintu masuk terdapat arca singa dalam posisi mendekam. Pada bagian dinding luar pintu masuk dipahatkan relief roda. Penggambaran relief tersebut tepat di belakang arca singa, sehingga memberi kesan seolah-olah snga ini sedang menarik roda (kereta?). Selain kedua arca singa tersebut, ditemukan juga 4 buah arca singa dalam posisı berdiri.

Tinggalan arkeologis lainnya yang berhasil dikumpulkan dari hasil penelitian yang dilakukan oleh Pusat Penelitian Arkeologi Nasional, EFEO, Proyek Penelitian Purbakala Palembang dan Balai Arkeologi Palembang sejak tahun 1990 sampai tahun 1993, antara lain: struktur bangunan beserta komponen-komponennya, "Ima buah arca (Siwa, Agastya, Nandi, Arca Permujudan 1, dan Arca Perwujudan 2), stambha, kotak peripih, yon dan fragmen prasasti bata. Komponen-komponen bangunan candı yang berhasil dikumpulkan dari Candi 1 ialah kemuncak candi, panil-panit hıasan tubuh candi, sım. bar, dan bata-bata berhias (huruf dan gambar) Di tebing Sungal Lematang, tidak jauh dari Candi 1 pemah ditemukan pula sebuah buli-bulı yang di delamnya berisi prasasti yang diguratkan pada lempengan emas. Di lokasi yang sama ditemukan juga fragmen keramik lokal dan asing dalam akumulasi yang cukup padat. 
Periodisasi Dan Latar Belakang Keagamaan Candi 1

\section{A. Periodisasi Candi 1}

Untuk mertentukan periodisasi suatu bangunan tinggalan masa lampau dapat digunakan beberapa cara, di antaranya ialah melalui prasasti, bentuk arsitektur, gaya seninya ataupun keramik asing yang ditemukan di sekitar situs atau bangunan. Ditinjau dari cara pemahatannya, arca-arca singa dari Candi 1 mirip dengan arca sınga yang terdapat di Candi Borobudur. Berdasarkan persamaan langgam tersebut dapat diperkirakan bahwa Candi 1 didirikan pada kurun waktu yang sama dengan Candi Borobudur, yaitu antara abad ke-8-10 M (Poespone. goro dan Nugroho Notosusanto, 1884: 110).

Kala yang merupakan komponen bangunan candi ditemukan di antara runtuhan pintu masuk Candi 1. Hiasan kala ditempatkan pada ambang pintu masuk atau relung candi, digambarkan tanpa rahang bawah. Ciri-ciri kala tersebut dijumpai juga pada kala-kala yang terdapat pada candi-candi periode Jawa Tengah. Dengan demikian dapat diperkirakan bahwa pendirian Candi 1 sejaman dengan periode Jawa Tengah (antara abad ke-8 sampai ke-10 M).

Ditinjau dari bentuk arsitekturnya, Candi 1 diduga berasal sekitar abad ke-8. $\mathrm{Hal}$ ini terlihat pada bentuk denah bujur sangkar. Hal tersebut didasarkan pada asumsi Soekmono yang menyatakan ciri-ciri sebuah candi masa awal di Indonesia berdenah bujursangkar. dan berpenampil satu pada pintu. Gejala tersebut ditemukan pada bangunan tahap pertama Candı 1. Pendukung lain berupa bentuk profil bagian kaki candi, mempunyai hiasan pelipit sisi genta (padma) dan pelipit setengah lingkaran (kumuda). Profil candi serupa juga dijumpai pada candi-candi yang berasal dari abad ke-8-10 $M$, misalnya Candi Mendut dan Prambanan

Petunjuk lain yang dapat digunakan sebagai identifikasi pertanggalan ialah stambha, yang digambarkan dalam bentuk tiga tokoh dalam satu arca. Ketiga makhluk tersebut terdiri dari: gajah terletak di bagian paling bawah, ghena (makhluk kerdil) di atasnya, sedangkan bagian paling atas ialah singa. Menurut Bambang Budi Utomo, stambha ini menggambarkan sengkalan memet (candra-sangkala yang menggunakan gambar). Jika dugaan tersebut benar, maka arca tersebut menggambarkan angka tahun $818 \mathrm{C}$ atau $896 \mathrm{M}$

Di samping data-data di atas, identifikasi pertanggalan Candi 1 dapat diketahui pula dari temuan prasasti dan bata-bata bertuliskan huruf Jawa kuno. Pada tahun 1991 ditemukan sebuah lempengan emas dari dalam sebuah buli-buli di sekitar lokasi Candi 1. Di atas lempengan emas Inı tertera tulisan (hasil pembacaan M.M. Soe- karto Karto Atmodjo) Dowi Prtiwi dan Dewa Agni. Ditinjau dari paleografinya tulisan pada lempengan emas tersebut berasal antara abad ke10 dan ke-12 M. Selain itu, padfa tahun 1993 ditemukan sebuah fragmen prasasti yang digoreskan pada bata, terdiri dari tiga baris. Berdasarkan hasil pembacaan Soekarto tulisan tersebut berbunyi: I. yalu ....; 2. ka kanya si ...; dan 3. kata dkat ... (kawa dkat ...). Berdasarkan paleografinya diperkirakan berasal dari kurun waktu antara abad ke 10-11 M. Karena tulisannya tidak utuh lagi, maka maksud dan maknanya tidak dapat diketahui dengan pasti

Dari data keramik Cina yang berhasil dikumpulkan di situs ini dapat diketahui pula identifikasi pertanggalan situs, yaitu antara abad 10 $14 \mathrm{M}$. Hasil analisis menunjukkan bahwa keramik-keramik tersebut berbentuk mangkuk, piring, tempayan, dan cawan, yang berasal dan masa dinasti Song (abad 10-12 M) dan dinasti Song-Yuan (abad 13-14 M). Fragmen keramik yang paling dominan ditemukan ialah keramik dari masa dinasti Song yang berasal dari abad ke-10 - $12 \mathrm{M}$.

Selain arca-arca singa yang bergaya Jawa Tengah, arca-arca lain yang ditemukan di situs Candi 1 memiliki gaya kesenian darı periode Jawa Timur, khususnya pada bagian rambutnya Ditinjau dari ikonografinya, kelembutan, keindahan (detail) hiasan maupun postur tubuhnya menunjukkan persamaan dengan arca-arca yang ditemukan di Candi Gurah, Jawa Timur. Menurut Soekmono candi tersebut berasal dari masa peralihan antara kesenian Jawa Tengah dan Jawa Timur, yaitu antara abad ke-10 - ke $11 \mathrm{M}$.

\section{B. Latar Belakang Keagamaan Candi 1}

Berdasarkan temuan arca-arca yang tendentifikasi dapat diketahui latar belakang keagamaan Candi 1, yakni Hindu. Arca-arca tersebut berupa arca Siwa, Agastya dan Nandi. Temuan lempengan emas menyebut nama Dewi Prtim dan Dewa Agni, yang termasuk dewa-dewa dalam pantheon agama Hindu memperkuat dugaan ini. Sifat ke-Hindu-an Candi 1 tampak pula dari hasil penelitian Peter Ferdinandus berdasarkan data-data geologis yang ditemukan di sekitar situs. Lebih lanjut dikatakan bahwa adanya sungai-sungai yang mengelingi situs dan satu sama lain saling bertemu menunjukkan bahwa Candi 1 didirikan berdasarkan konsep Hindu (1993:36). Adanya cerita penduduk tentang adanya sumber mata air yang disebut "Tuluk Tujuh" dapat dikaitkan dengan tujuh buah sungai suci yang dikenal di India, yakni Sungai Gangga, Yamuna, Godawari, Saraswati, Narmada, Sarayu dan Gomati.

Sifat kehinduan candi ini terlihat juga dari bentuk hiasan atap berupa ratna. Pada candi- 
cand yang berlatarbelakang agama Buda atap bangunannya dihiasai dengan stupa.

Berdasarkan data yang telah diuraikan $\mathrm{d}$ atas dapat diketahuı periodisası Candi 1. sekitar abad ke-8 - $14 \mathrm{M}$, sedangkan agama yang mendasarı pembangunannya adalah agama Hindu.

\section{Bata Bertulis dan Tahap-tahap Pembangunan Candi}

Gejala-gejala yang tampak pada bentuk arsitektur bangunan menunjukkan bahwa Candi 1 pernah mengalamı pengembangan dan penambahan dalam pembangunannya. Hal ini terlinat dari bentuk arsttektural yang masih tertınggal. Bukti di lapangan menunjukkan bahwa bangunan candi didirikan tidak kurang dari tiga tahap pembangunan. Dengan demikian memungkinkan terjadinya penambahan komponenkomponen bangunan candi yang sebelumnya tıdak atau belum ada. Bukti adanya penambahan terungkap dari bentuk profil kaki candi di sebelah timur yang sengaja ditutup dan kemudian ditambahkan bangunan penampil pintu rnasuk. Adanya pilaster-pilaster rendah tanpa profil Jari bata yang ditemukan pada sudut-sudut bangunan memperkuat dugaan di atas. Perbedaan warna dan susunan bata yang tidak menyatu dengan struktur kak! bangunan memperlihatkan pilaster-pilaster tersebut merupakan tambahan, jang semula tidak termasuk dalam rancangan arsitektur bangunan candi yang asli. Hal ini terlihat pada singkapan susunan bata pada kaki sand yang kelihatan masih tampak di belakang pllaster (Anton Herrystiadi, dkk. 1993:1333). Keadaan ını menimbulkan kesan bahwa penampil dan pilaster menempel pada bangunan asli, sehingga secara struktural lepas dari bangunan induknya, seperti yang terlihat pada penampil di sebelah barat gang terlepas darı bangunan in. duk akibat melesaknya pondasi.

Kesan adanya tiga tahap pembangunan Candı 1 dibuktikan pada sistem perpelipitan yang terdapat pada penampil pintu masuk sebelah timur. Bentuk pelipit padma (sisi genta), jala dan kumuda (pelipit setengah lingkaran) yang terdapat pada bag!ıın ketiga (bangunan asli) tidak dijumpai pada bangunan penampil yang terletak di depannya.

Berdasarkan bukti-bukti yang telah dikemukakan di atas dapat diperkirakan Candi 1 didirikan dalam tiga tahap. Tahap | candi dibangun dengan denah berbentuk segi empat (bujursangkar), tanpa penampil, tangga dan pintu masuk. Pada tahap II ditambahkan bingkai-bingkal mistar, bingkai setengah lingkaran dan sisi genta (ojief). Baru pada tahap III ditambahkan oagian-bagıan penampil, yang menjorok keluar pada keempat sisinya dan memberikan semacam ruangan (antarala) dengan pintu masuk di sebelah timur dan pilaster. Apapıla dikartkan dengan periodisasi candi 1 antara abad 8-14 M diduga bahwa pendirian cand tahap I dliakukan sekitar abad ke-8 - $10 \mathrm{M}$, sedangkan tahap I dan III dikerjakan pada abad ke-10 - $12 \mathrm{M}$ Perkiraan tersebut didasarkan pada bentuk profil kaki candi asli serta gaya senı arca sınga dan hiasan kala yang menunjukkan gaya senı Jawa Tengahan atau Syailendra, yang Derkembang antara abad ke-8 - $10 \mathrm{M}$. Pembangunan tanap ॥ kemungkinan terjadı antara abad ke-10 - $11 \mathrm{M}$ sedangkan pembangunan tahap Ilf berlangsung pada kurun waktu antara abad $11.12 \mathrm{M}$ Hal in didasarkan pada temuan fragmen prasast casa bata yang berasal varı abad yang sama irca. arca lainnya yang ditemukan di sekitar cano k.e. mungkinan ditambahkan pada pembangunan tahap III ini. Penambarian penampil pıntu masuk candi yang memuat relief roda di belakang arca singa mungkın diadaptasi dari India Selatan, te patnya di Konarak. Di Candi KulottungacholaMarttandalaya yang didirikan oleh Choia Kulottungacholadeva (1060 - $1118 \mathrm{M})$. Caridi yang di. peruntukkan untuk dewa Surya tersebut juga d!temukan relief roda kereta yang ditarik oleh sInga. Maksud penggambaran relief tersebut tidak diketahui secara pasti, mengingat kereta yang menjadi wahana arca Surya biasanya digambar. kan ditarik oleh tujuh ekor kuda, bukannya singa.

Pentahapan pembangunan candı ını kemungkinan dikaitkan dengan makin dertambah. nya umat yang mamantaatkannya Adanya temuan yoni (biasanya dikaitkan dengan lingga; dan arca Siwa Mahadewa di lokas candi, alduga berkaitan dengan tahap-tahap pembangunannya. Lingga-yoni dan arca Siwa Mahadewa menempati ruangan itama suatu vangunan candi, sehıngga pemujaan keduanya mengınd:kasikan adanya penggantian kedudukan lınggayoni dengan arca Siwa Mahadewa dalam ruangan utama candı. Pada pembangunan tahap I diperkirakan ruangan utama ataupun relung utama ditempati oleh lıngga dan yoni. Hal tersebut seperti penempatan arca Ganesha pada Candı Gebang di Yogyakarta. Selanjutnya. perluasan bangunan candi dengan penambahan ruangan dan relung-relung di ketiga sısı iaınnya memungkinkan penggantian lıngga-yonı dengan arca Siwa Mahadewa, sedangkan relung-reiung lainnya ditempatı oleh dewa-dewa yang iaın (biasanya, arca Agastya menempati relung selatan, arca Durga relung utara dan Ganesha ar relung barat ika candi menghadap ke timur atau di sebelah timur, jika candinya menghadap ke barat). Adapun arca Nandı. Perwujudan 1 đan 2 belum dapat dipastikan penempatannya Kemungkinan ditempatkan di candi-canal perwara 
yang terletak di depan dan di sebelah utara Candi 1.

\section{Candi 1 dan Latar Belakang Sejarahnya}

Berdasarkan uraian di atas dapat diketahui bahwa pembangunan Candi 1 menunjukkan adanya pengaruh kesenian Jawa Tengah dan Jawa Timur. Selain itu terlihat Juga adanya pengaruh Chola, India Selatan dalam pahatan hiasannya. Untuk lebih memahami adanya persamaan-persamaan gaya seni tersebut perlu diketahu। latar belakang sejarah yang terjadi pada kurun waktu itu

Temuan arkeologis di kawasan Sumatera umumnya dan Sumatera Selatan khususnya, selama ini selalu dikaitkan dengan keberadaan Kerajaan Sriwijaya. Kerajaan ini mulai dibicarakan para sejarawan berkaitan dengan penemuan lima buah prasasti di Palembang. Bangka, Jambi dan Lampung. Prasasti-prasasti tersebut adalah prasasti Kedukan Bukit, Talang Tuo, Kota Kapur, Telaga Batu, Karang Berahi, dan Palas Pasemah yang berasal dari abad ke-7 $M$ (682-686 M.). Dengan ditemukannya Prasasti Boom Baru pada tahun 1991 yang berasal dari periode yang sama menambah data baru mengenai eksistensi kerajaan Sriwijaya di masa lampau. Setełah abad itu, tidak banyak yang diketahui tentang Sriwijaya dari prasasti. Keterangan-keterangan yang berkaitan dengan Sriwijaya lebih banyak diketahui dari sumber berita asing, terutama berita Cina, yang mencatat kedatangan utusan-utusan dari Sriwijaya pada tahun 695 - 742 M. Setelah kurun waktu itu, tidak ada satu catatan pun yang memberitakan tentang duta-duta kerajaan Sriwijaya di Cina. Dengan demikian tidak dapat diketahui aktivitas yang berlangsung pada waktu itu, sampai ditemukannya Prasasti Ligor berangka tahun $725 \mathrm{M}$. Berdasarkan prasasti tersebut beberapa ahli mengasumsikan bahwa keluarga Syailendra pernah berkuasa di Sriwijaya pada abad ke-8 M. Atas dasar itulah dapat diduga bahwa sejak abad inilah pengaruh-pengaruh kesenian Syailendra masukke Sumatera dan terus berkembang pada masa berikutnya, yaitu pada masa pemerintahan Balaputradewa pada abad ke-9 M seperti yang disebutkan dalam prasasti Nalanda (860 M.). Dalam prasasti ini disebutkan bahwa, Balaputra adalah anak dan Samaragrawira dan cucu dari raja Jawa yang menjadi "Mustika keluarga Syailendra" bernama Sn Wirawanimathana. Pemberitaan tentang berkuasanya Balaputradewa di Sriwijaya di dukung ditemukannya prasasti Siwagerha di Prambanan, yang menguraikan tentang peperangan Balaputradewa dengan iparnya, Rakai Pikatan (Casparis, 1956: 280-330). Dalam peperangan tersebut Balaputradewa mengalami ke- kalahan dan kemudian melarikan diri ke Swarnadwipa dan menjadi raja di Sriwijaya Tankh prasasti Siwagerha ialah 12 Nopember 856, jad sejaman dengan prasasti Nalanda.

Berdasarkan uraian di atas dapat disimpulkan bahwa yang membawa.pengaruh Jawa di Sumatera pada awalnya adalah Balaputradewa, yang pemah tinggal di Jawa. Pada masa itu di daerah Mataram banyak didirikan candi. candi, baik Hindu maupun Budha. Berdasarkan temuan prasasti Sojomerto yang menyebutkan nama Dapunta Selendra dapatlah diasumsikan bahwa hanya ada satu dinasti di Mataram, yaitu Dinasti Syailendra (seperti yang dikemukakan oleh Boechari dan Poerbatjaraka) Selanjutnya disimpulkan bahwa kehidupan keagamaan di Mataram pada waktu itu berjalan secara berdampingan.

Melihat keadaan di Jawa seperti itu, ruparupanya Balaputra kemudian menerapkannya d Sriwijaya. Meskipun dia sendiri memeluk agama Budha, yang kemungkinan juga merupakan agama negara, tetapi dia tidak melarang rakyatnya untuk memeluk agama Hindu dan mendirikan bangunan suci untuk melakukan penbadatan. Kemungkinan pula yang membangun Candi 1 adalah para pengikut setia Balaputradewa yang beragama Hindu dan ikut melarikan diri ke Sumatera sewaktu Balaputradewa kalah perang melawan Rakai Pikatan. Jika melihat lokasi situs Bumiayu yang Jauh dari pusat pemerintahan, dapat diasumsikan pula bahwa agama Budha dianut oleh penduduk yang tingal di pusat pemerintahan, sedangkan penduduk ping. giran menganut agama Hindu. Pengaruh Jawa tersebut tidak hanya berhenti pada masa pemerintahan Balaputradewa tetapi berlanjut pada masa kemudian.

Perlu diketahui selain Balaputradewa, Marawijayottunggawarman (memerintah setelah abad ke-10) juga mengaku keturunan Syailendra. Raja ini menjalin hubungan persahabatan dengan raja Chola di India yang telah dirintıs oleh ayahnya, Sri Chulamaniwarmadewa. Pada tahun 1005 raja tersebut mendirikan vihara di Negapatam yang diberi nama Vihara Chulamaniwarmadewa. Raja-raja I dari Chola menghadiahkan hasil pajak tahunan sebuah desa besar untuk dipeliharanya (Hall, 1988: 55) Pada masa pemerintahan Rajendrachola hadiah tersebut tetap dipertahankan, bahkan lebih besar. Dengan adanya persahabatan yang terjalin antara masyarakat kedua kerajaan, tentunya masingmasing membawa budayanya. Kemungkinan inilah yang mempengaruhi pembuatan relief roda di belakang arca singa di Bumıayu, yang mempunyai persamaan dengan relief dı Konarak. Candi untuk Dewa Surya di Konarak didiri. kan pada tahun 1026 sejaman dengan pendirian 
candı Surya di Martano, Orissa dan Siraj Kund di New Delhi (Grover, 1980:181). Berdasarkan data tersebut dapat diperkirakan pembangunan tahap II Candi 1 berlangsung setelah abad ke$10 \mathrm{M}$. Hal ini didasarkan pada masa pemerintahan Chola yang mendominasi India Selatan sejak abad 10 dan $11 \mathrm{M}$, yang dikenal dengan periode Pallawa (Ibid:193).

Pada masa akhir kekuasaan kerajaan Sriwijaya, yang berkuasa di Jawa Timur adalah Dharmawangsa Teguh (sekitar abad ke-10 M), yang kemudian digantikan oleh Airlangga (abad ke-11 M) (Casparis, 1958). Pada masa pemerintahan Dharmawangsa Teguh inilah Sriwijaya mendapat serangan dari Jawa, seperti yang disebutkan dalam berita Cina dari masa dinasti Sung (Groeneveldt, 1960:6566). Peristiwa tersebut terjadi pada tahun $992 \mathrm{M}$. Perselisihan pada tahun 992 ini diberitakan juga dalam kitab Chufanchi (Hirth and Rockhi 11,11967:62)

Pertentangan antara dua kekuasaan ini berlangsung cukup lama dan baru mencapai keseimbangan (perdamaian) pada masa pemerintahan Airlangga (Ibid). Seperti tercatat dalam prasasti dan karya kesusasteraan kedua raja dari Jawa Timur tersebut menganut agama Hindu. Berdasarkan data ini dapat diperkirakan bahwa pengaruh kesenian Jawa Timur di Candi 1 berlangsung pada kurun waktu antara abad ke-10-11 M. Hal ini diperkuat dengan temuan fragmen prasasti bata di Candi 1 yang ditulis dalam huruf Jawa Kuna dan berasal dari abad ke-10-11 M

Merujuk pada uraian di atas dapatlah diketahui bahwa pada masa kerajaan Sriwijaya tidak hanya berkembang agama Budha saja, tetapi juga agama Hindu. Raja-raja yang memerintah di Sriwijaya pada waktu itu memberikan kebebasan kepada rakyatnya untuk memeluk agama menurut kepercayaan mereka masingmasing Pada masa awal pembangunannya, Candi 1 didirikan dan diperuntukkan bagi para pengikut Balaputra Dewa. Pada masa pembangunan berikutnya barulah pengaruh kesenian Jawa Timur turut memperkaya dan mempercantık bangunan Candi 1. Pemanfaatan situs Bumiayu sebagai sarana peribadatan para penganut Hindu diduga berlangsung sampai sekitar abad ke-14 $M$, sesuai dengan kronologi situs seperti yang telah diungkapkan di atas.

\section{KEPUSTAKAAN}

Anton Herrystiadi,dkk., 1993 Candi I Situs Bumiayu, Suaka Peninggalan Sejarah dan Purbakala Propinsi Jambi, Sumatera Selatan dan Bengkulu, (belum diterbitkan)
Bambang Budi Utomo: 1993 Penelitian Arkeologı Situs Percandian Tanah Abang Tahun 1991 dan 1992. Pusat Penelitian Arkeologi Nasional (belum diterbitkan)

1993, Menyingkap Lumpur Lematang. Sriwijaya dalam Perspektif Arkeologi dan Sejarah. Pemda Tk I Sumsel

Boechari, M.,1977, Epigrafi dan Sejarah Indonesia, Majalah Arkeologi Th. I No. 2 November him. 1-35

-1977, Bahan Kajian Arkeologi Untuk Pengajaran Sejarah, PIA II, Jakarta: Pusat Penelitian Arkeologi Nasional. him. 3-26

Casparis,J.G.de,1956, Selected Inscription from 7th to the 9th Century A.D. Prasasti Indonesia II. Bandung: Masa Baru

1958, Airlangga, Pidato Pengukuhan Sebagai Guru Besar Perguruan Tinggı IImu Sejarah Universitas Airlangga di Malang. Surabaya: Penerbitan Universitas

Groeneveldt,W.P. 1960, Historical Notes on Indonesia and Malaya Compiled from Chinese Sources, C.V. Bhratara

Grover,Satish,1980, The Architecture of India Budhis and Hindu, India: Vikas Publishing House PVT Ltd

Hall,D.G.E.,1988, Sejarah Asia Tenggara, Surabaya: Usaha Nasional

Hirth,F and W.W Rockhill, 1911, reprint 1967 Chau Ju-Kua, St. Petersburg

Machi Suhadi, 1983, Seven Old-Malay inscription Found In Java, SPAFA Consultatif Workshop on Archaeological and Environmental Studies on Srivijaya, $\mathrm{hlm}$ 67-81

Marwatı Djoned Poesponegoro dan Nugroho Notosusanto, 1984, Sejarah Nasional Indonesia II, Jakarta: PN Balai Pustaka

Peter Ferdinandus, 1993, Peninggalan Arsitektur darı Situs Bumi Ayu Sumatera Selatan Amerta 13. Jakarta: Pusat Penelitian Arkeologi Nasıonal. Him. 33-38

Romond, V.R van, 1985, Sebuah Candı Timbul Kembali, Amerta Jakarta: Pusat Penelitian Arkeologı Nasional, him 3944 
Satyawati Sulaiman,1983, The Role of The Sailendras in Srivijaya, SPAFA Consultatif Workshop on Archaeological and Environmental Studies on Srivijaya hIm. 61-5

Slamet Muljana,1981, Kuntala, Sriwijaya dan Suwarnabhumi, Jakarta: Yayasan Idayu.

Sukarto K.Atmodjo, 1985, Short Notes on The Old lalay Inscription in Central Java, SPAFA Consultatif Workshop on Archaeological and Environmental Studies on Srivijaya, hIm. 81-95. 